\title{
Pertumbuhan dan Perkembangan Anak Usia 3-24 Bulan di Daerah Konflik
}

\section{Growth and Development of Children 3-24 Months in the Conflict Area}

\author{
Hastuti Usman*, Hadyana Sukandar**, Ma’mun Sutisna****
}

\author{
*Jurusan Kebidanan Politeknik Kesehatan Kementerian Kesehatan Palu, **Fakultas Kedokteran Universitas \\ Padjajaran, ***Politeknik Bandung
}

\begin{abstract}
Abstrak
Lima tahun pertama adalah masa penting dalam proses tumbuh kembang anak. Anak lahir dan tinggal di daerah rawan bencana (bencana alam, perang, atau konflik bersenjata) berisiko mengalami kegagalan pertumbuhan dan keterlambatan perkembangan. Penelitian ini bertujuan mengukur perbedaan pertumbuhan dan perkembangan anak usia 3 - 24 bulan antara yang tinggal di daerah konflik dan bukan konflik dan menganalisis korelasi tempat tinggal daerah konflik dengan pertumbuhan serta perkembangan anak usia 3 - 24 bulan. Metode penelitian secara potong lintang dilakukan di Kabupaten Poso periode Februari - Maret 2014 terhadap 40 anak usia 3 - 24 bulan di daerah konflik dan bukan konflik. Data dianalisis menggunakan kai kuadrat dan korelasi point biseral. Hasil pertumbuhan berdasarkan berat badan/panjang badan di daerah konflik dan bukan konflik, kurus berturut-turut $32 \%$ dan $2 \%(p<0,001)$, sedangkan perkembangan yang meragukan berturut-turut $30 \%$ dan $5 \%(p=0,006)$. Berdasarkan lingkar kepala pertumbuhan tidak normal masing-masing $17 \%$ dan $0 \%(p=0,006)$. Variabel perancu (jenis kelamin, pendidikan ibu, penghasilan) tidak memengaruhi pertumbuhan anak usia 3-24 bulan di daerah konflik ( $p>0,05)$, tetapi jenis kelamin memengaruhi perkembangan $(p=0,010)$. Pertumbuhan dan perkembangan anak usia 3-24 bulan yang tinggal di daerah konflik lebih terganggu dibandingkan dengan yang tinggal di daerah bukan konflik. Terdapat korelasi antara tempat tinggal daerah konflik dan jenis kelamin anak dengan pertumbuhan dan perkembangan anak usia 3-24 bulan.

Kata kunci: Daerah bukan konflik, daerah konflik, perkembangan pertumbuhan
\end{abstract}

\section{Abstract}

The first five years are an important period in the development of the child. Children born and living in areas prone to disasters (natural disasters, war or armed conflict), risk of growth failure and developmental delay. This study aimed to measure the difference in the growth and development of children aged between 3 - 24 months who live in areas of conflict and not conflict and analyze correlations residential areas of conflict with the growth and development of children aged 3 - 24 months. Method of cross-sectional studies conducted in Poso regency February - March 2014 to children aged 3 - 24 months in areas of conflict and not conflict. Data were analyzed using chisquare and correlation point biseral.The results based on the growth of weight /height in conflict areas and not conflict, successive thin $32 \%$ and $2 \%$ $(p<0.001)$, whereas the development of the doubt in a row $30 \%$ and $5 \%$ $(p=0.006)$. Based on head circumference abnormal growth respectively $17 \%$ and $0 \%(p=0.006)$. Confounding variables (gender, maternal education, income) does not affect the growth of children aged 3 - 24 months in areas of conflict ( $p>0.05)$, but influence the development of gender $(p=0.010)$. Conclusions growth and development of children aged 3 - 24 months who live in areas of conflict more disturbed than those living in areas not conflict. There is a correlation residential areas of conflict and gender of children with the growth and development of children 3-24 months of age.

Keywords: Not a conflict area, regional conflict, the development of growth

\section{Pendahuluan}

Masa balita yang disebut dengan golden periode, dan masa batita yang disebut masa critical periode merupakan masa pertumbuhan dan perkembangan yang paling pesat pada otak manusia, masa ini otak bersifat plastis dibandingkan dengan orang dewasa sehingga balita sangat terbuka dan peka dalam menerima berbagai macam pembelajaran dan pengayaan baik bersifat positif maupun negatif. Tumbuh kembang balita akan optimal jika lingkungan memberikan dukungan yang positif atau sebaliknya. 1,2

Korespondensi: Hastuti Usman, Poltekkes Kemenkes Palu Jurusan Kebidanan, Jl. Thalua Konchi No. 13 Mamboro Palu Sulawesi Tengah, Hp. 081341352373,e-mail: hastutiu@ymail.com 
Pertumbuhan dihubungkan dengan penambahan jumlah dan besar sel tubuh dan dapat dilihat dari berat badan, tinggi badan, dan lingkar kepala. Pada dasarnya, setiap anak akan melewati proses tumbuh kembang sesuai dengan tahapan usianya, akan tetapi banyak faktor yang memengaruhi di antaranya faktor genetik dan lingkungan sejak prenatal, perinatal, dan postnatal. ${ }^{3}$ Faktor lingkungan adalah faktor yang menentukan tercapai atau tidaknya potensi bawaan yang terdiri atas lingkungan bio-psiko-sosial. ${ }^{1}$ Faktor lain yang memengaruhi tumbuh kembang anak yaitu faktor usia anak, pendidikan ibu, penghasilan keluarga, jumlah anak, beban kerja ibu, pola asuh psikososial, kepribadian orangtua, adat istiadat, agama, urbanisasi, kehidupan berpolitik, dan stimulasi yang diberikan oleh orangtua. 4,5,6

Keterlambatan pertumbuhan dan perkembangan merupakan masalah yang serius bagi negara maju maupun negara berkembang di dunia. Angka kejadian di Amerika Serikat berkisar 12-16\%, Argentina 22\%, dan Hongkong 23\%.7,8 Profil kesehatan Indonesia tahun 2011 menunjukkan bahwa 13-18\% mengalami keterlambatan perkembangan. ${ }^{9,10}$

Tumbuh kembang anak yang optimal berhubungan dengan lingkungan tempat lahir dan tinggal anak. ${ }^{11}$ Anak yang lahir dan tinggal di daerah yang rawan terjadi bencana baik berupa bencana alam, perang, atau konflik bersenjata berisiko tinggi mengalami kegagalan pertumbuhan dan keterlambatan perkembangan. ${ }^{12}$

Dampak perang di Afganistan menyebabkan anak secara fisik dapat terjadi kekurangan gizi, penyakit (malaria, ISPA, cacar), cedera, cacat, dan secara psikologik anak mengalami trauma, hal ini akan memengaruhi mortalitas dan morbiditas. ${ }^{13,14}$ Penelitian yang dilakukan oleh Jeharsae dkk., ${ }^{15}$ pada anak usia 1 - 5 tahun di daerah konflik Thailand menunjukkan gangguan pertumbuhan dengan prevalensi underweight 19,3\%, stunting $27,6 \%$, dan wasting $7,4 \%$ dan keterlambatan perkembangan meliputi kemampuan gerak kasar, gerak halus, bahasa dan bicara, serta sosialisasi dan kemandirian yaitu $31,1 \%$. Hasil penelitian lain di Maluku yang merupakan daerah pascakonflik dengan subjek penelitian 2.168 anak usia 0-59 bulan menunjukkan prevalensi stunting dan stunting berat $29 \%(95 \% \mathrm{CI}=26,0-32,2)$ dan $14,1 \%$ $(95 \% \mathrm{CI}=35,9-41,0)$ dan untuk anak $0-23$ bulan $38,4 \%$ $(95 \% \mathrm{CI}=35,9-41,0)$ dan $18,4 \%(95 \% \mathrm{CI}=61,1-20,9)$. Faktor risiko untuk anak yang mengalami keterlambatan adalah usia anak, jenis kelamin, jumlah makan per hari, dan penghasilan keluarga. ${ }^{16}$

Kabupaten Poso adalah salah satu kabupaten di Provinsi Sulawesi Tengah yang sampai saat ini dikategorikan daerah konflik, terdiri atas 21 kecamatan dengan 5 kecamatan yang paling rawan terjadi konflik bersenjata antar-aparat keamanan dan masyarakat. Situasi ini akan sangat berpengaruh pada proses kehidupan masyarakat khususnya keluarga yang akan merasa ketakutan dan khawatir akan keselamatan jiwanya. Terfokusnya keluarga khususnya ibu pada keselamatan jiwa maka perhatian terhadap kebutuhan anak baik kebutuhan fisik maupun psikologis akan berkurang yang akan memengaruhi terganggunya tumbuh kembang anak.

Bidan berdasarkan kewenangannya dapat melakukan pemantauan pertumbuhan dan perkembangan pada anak balita melalui program pemerintah untuk pemantauan tumbuh kembang anak dilakukan sejak usia 3 bulan sampai 72 bulan, ${ }^{17}$ yang bertujuan untuk mendeteksi penyimpangan tumbuh kembang serta dapat melakukan intervensi sedini-dininya untuk memperbaiki penyimpangan yang terjadi dan jika perlu dilakukan rujukan sesuai dengan indikasi. ${ }^{2}$ Pengukuran antropometri dapat menggambarkan pertumbuhan anak dan setiap pertanyaan pada KPSP menggambarkan salah satu aspek perkembangan yaitu perkembangan motorik kasar, motorik halus, bicara dan bahasa, serta sosialisasi dan kemandirian. Kuesioner ini dipilih karena penggunaannya mudah, cepat, dapat diterapkan pada sarana kesehatan dasar, dan dapat mengetahui apakah pertumbuhan dan perkembangan anak normal atau terdapat penyimpangan. ${ }^{2}$ Tujuan dalam penelitian ini adalah mengukur perbedaan pertumbuhan dan perkembangan anak usia 3 - 24 bulan antara yang tinggal di daerah konflik dan bukan konflik dan menganalisis korelasi tempat tinggal daerah konflik dengan pertumbuhan serta perkembangan anak usia 3 - 24 bulan.

\section{Metode}

Penelitian ini menggunakan rancangan penelitian studi analitik komparatif dengan strategi pendekatan potong lintang. Subjek dalam penelitian ini adalah anak sehat usia 3 - 24 bulan yang berdomisili di daerah konflik dan bukan konflik. Penelitian ini dilakukan pada bulan Februari sampai dengan Maret 2014. Pengambilan sampel dengan teknik random sampling yang masing-masing daerah berjumlah 40 orang.

Pengumpulan data pada penelitian ini dengan cara melakukan pengukuran pertumbuhan yang meliputi penimbangan berat badan dengan menggunakan timbangan bayi dan timbangan injak. Pengukuran tinggi badan dan lingkar kepala menggunakan sentimeter, serta pengisian kuesioner pra skrining perkembangan (KPSP) yang terdiri dari 10 daftar pertanyaan. Pengukuran ini dilakukan oleh bidan yang ada di puskesmas tempat penelitian.

Analisis data dilakukan dengan menggunakan uji-t tidak berpasangan untuk mengetahui perbedaan pertumbuhan dan perkembangan anak usia 3 - 24 bulan di daerah konflik dan daerah bukan konflik, atau uji Mann Whitney jika data tidak berdistribusi normal, uji kai kuadrat untuk menganalisis perbedaan dua kelompok da- 
Tabel 1. Distribusi Frekuensi Demografi Subjek Penelitian di Daerah Konflik dan Bukan Konflik

\begin{tabular}{|c|c|c|c|c|c|c|}
\hline \multirow{3}{*}{ Karakteristik Demografi } & \multirow{3}{*}{ Kategori } & \multicolumn{4}{|c|}{ Daerah Penelitian } & \multirow{3}{*}{ Nilai $p$} \\
\hline & & \multicolumn{2}{|c|}{ Konflik } & \multicolumn{2}{|c|}{ Bukan Konflik } & \\
\hline & & $n=40$ & $\%$ & $n=40$ & $\%$ & \\
\hline \multirow[t]{8}{*}{ Usia anak (bulan) } & 3 & 4 & 10 & 13 & 32 & 0,297 \\
\hline & 6 & 6 & 15 & 7 & 17 & \\
\hline & 9 & 8 & 20 & 3 & 7 & \\
\hline & 12 & 6 & 15 & 3 & 7 & \\
\hline & 15 & 5 & 13 & 4 & 10 & \\
\hline & 18 & 6 & 15 & 6 & 15 & \\
\hline & 21 & 3 & 7 & 2 & 5 & \\
\hline & 24 & 2 & 5 & 2 & 5 & \\
\hline \multirow[t]{2}{*}{ Jenis kelamin anak } & Laki-laki & 12 & 30 & 20 & 50 & 0,068 \\
\hline & Perempuan & 28 & 70 & 20 & 50 & \\
\hline \multicolumn{7}{|l|}{ Karakteristik ibu } \\
\hline \multirow[t]{2}{*}{ Pendidikan } & Pendidikan Dasar & 30 & 91 & 3 & 21 & 0,001 \\
\hline & Pendidikan Tinggi & i 10 & 8 & 37 & 79 & \\
\hline \multirow[t]{2}{*}{ Penghasilan } & Rendah & 33 & 82 & 14 & 29 & 0,001 \\
\hline & Tinggi & 7 & 18 & 26 & 65 & \\
\hline
\end{tabular}

Tabel 2. Perbedaan Pertumbuhan Anak Usia 3-24 Bulan di Daerah Konflik dengan Bukan Konflik

\begin{tabular}{|c|c|c|c|c|c|c|}
\hline \multirow{3}{*}{ Pertumbuhan } & \multirow{3}{*}{ Kategori } & \multicolumn{4}{|c|}{ Daerah Penelitian } & \multirow{3}{*}{ Nilai $p$} \\
\hline & & \multicolumn{2}{|c|}{ Konflik } & \multicolumn{2}{|c|}{ Bukan Konflik } & \\
\hline & & Jumlah & $\%$ & Jumlah & $\%$ & \\
\hline \multicolumn{7}{|l|}{ Antropometri } \\
\hline \multirow[t]{2}{*}{$\mathrm{BB} / \mathrm{PB}$} & Normal & 27 & 68 & 39 & 98 & 0,001 \\
\hline & Kurus & 13 & 32 & 1 & 2 & \\
\hline \multirow[t]{2}{*}{ Lingkar kepala } & Normal & 33 & 83 & 40 & 100 & 0,006 \\
\hline & Tidak normal & 7 & 17 & 0 & 0 & \\
\hline
\end{tabular}

Keterangan: $\mathrm{BB}=$ berat badan, $\mathrm{PB}=$ panjang badan

Tabel 3. Perbedaan Perkembangan Anak Usia 3-24 Bulan di daerah Konflik dan Bukan Konflik

\begin{tabular}{|c|c|c|c|c|c|}
\hline \multirow{3}{*}{ Perkembangan } & \multicolumn{4}{|c|}{ Daerah Penelitian } & \multirow{3}{*}{ Nilai $p$} \\
\hline & \multicolumn{2}{|c|}{ Konflik } & \multicolumn{2}{|c|}{ Bukan Konflik } & \\
\hline & Jumlah & $\%$ & Jumlah & $\%$ & \\
\hline Sesuai & 28 & 70 & 38 & 92 & 0,006 \\
\hline Meragukan & 12 & 30 & 2 & 5 & \\
\hline
\end{tabular}

ta kategorik dan analisis korelasi Point Biserial untuk mengukur kuatnya hubungan pertumbuhan dan perkembangan dengan daerah tempat tinggal.

\section{Hasil}

Berdasarkan Tabel 1, uji statistik untuk variabel usia anak dan jenis kelamin tidak berbeda antara daerah konflik dan bukan daerah konflik ( $p>0,05)$. Berdasarkan uji statistik variabel jenjang pendidikan dan penghasilan terdapat perbedaan antara daerah konflik dan bukan konflik $(\mathrm{p}<0,05)$.

Tabel 2 pertumbuhan anak usia 3 - 24 bulan daerah konflik BB/PB sebagian besar (68\%) normal, bukan kon- flik BB/PB sebagian besar (98\%) normal ( $\mathrm{p}=0,001)$. Lingkar kepala daerah konflik sebagian besar normal (33\%), lingkar kepala bukan konflik 100\% normal $(p=0,006)$. Terdapat perbedaan pertumbuhan antara daerah konflik dan bukan konflik yang sangat signifikan $(\mathrm{p}<0,005)$.

Tabel 3 perkembangan anak usia 3 - 24 bulan baik di daerah konflik dan bukan konflik sebagian besar sesuai yaitu $70 \%$ dan $92 \%,(p=0,006)$. Terdapat perbedaan perkembangan yang signifikan antara daerah konflik dan daerah bukan konflik $(\mathrm{p}<0,001)$.

Tabel 4 menunjukkan bahwa variabel perancu tidak memiliki hubungan yang bermakna dengan pertumbuhan 
Tabel 4. Hubungan Variabel Perancu terhadap Pertumbuhan Anak Usia 3-24 Bulan di Daerah Konflik

\begin{tabular}{|c|c|c|c|c|c|c|c|}
\hline \multirow{3}{*}{ Karakteristik } & \multirow{3}{*}{ Kategori } & \multicolumn{5}{|c|}{ Pertumbuhan } & \multirow{3}{*}{ Nilai $p$} \\
\hline & & \multicolumn{2}{|c|}{ BB/TB } & \multirow[t]{2}{*}{ Nilai p } & \multicolumn{2}{|c|}{ Lingkar Kepala } & \\
\hline & & Normal & Kurus & & Normal & Tidak Normal & \\
\hline \multirow[t]{2}{*}{ Jenis kelamin anak } & Laki-laki & 8 & 4 & 0,940 & 11 & 1 & 0,318 \\
\hline & Perempuan & 19 & 9 & & 22 & 6 & \\
\hline \multirow[t]{2}{*}{ Pendidikan ibu } & Pendidikan dasar & 20 & 10 & 0,845 & 25 & 5 & 0,810 \\
\hline & Pendidikan tinggi & 7 & 3 & & 8 & 2 & \\
\hline \multirow[t]{2}{*}{ Penghasilan } & Rendah & 21 & 12 & 0,257 & 27 & 6 & 0,805 \\
\hline & Tinggi & 6 & 1 & & 6 & 1 & \\
\hline
\end{tabular}

Tabel 5. Hubungan Variabel Perancu terhadap Perkembangan Anak Usia 3-24 Bulan di Daerah Konflik

\begin{tabular}{lllll}
\hline Karakteristik & Kategori & \multicolumn{2}{c}{ Perkembangan } & Nilai p \\
\cline { 3 - 4 } & & Sesuai & Meragukan & \\
\hline Jenis kelamin anak & Laki-laki & 5 & 7 & 0,010 \\
Pendidikan ibu & Perempuan & 23 & 5 & \\
& Pendidikan dasar & 20 & 10 & 0,152 \\
Penghasilan & Pendidikan tinggi & 9 & 1 & \\
& Rendah & 23 & 10 & 0,389 \\
& Tinggi & 6 & 1 &
\end{tabular}

Tabel 6. Korelasi Pertumbuhan dan Perkembangan Anak Usia 3-24 Bulan dengan Tempat Tinggal

\begin{tabular}{lcl}
\hline Korelasi Variabel & $\mathbf{r}_{\mathbf{p b i}}$ & Nilai $\mathbf{p}$ \\
\hline Pertumbuhan BB/PB dengan tempat tinggal & 0,395 & 0,001 \\
Pertumbuhan LK dengan tempat tinggal & 0,310 & 0,005 \\
Perkembangan dengan tempat tinggal & 0,329 & 0,006 \\
\hline
\end{tabular}

Keterangan: $\mathrm{r}_{\mathrm{pbi}}=$ berdasarkan koofisien korelasi poin bisereal

anak usia 3 - 24 bulan di daerah konflik $(\mathrm{p}>0,05)$

Tabel 5 menunjukkan bahwa variabel jenis kelamin memiliki hubungan yang bermakna dengan perkembangan anak usia 3 - 24 bulan di daerah konflik $(\mathrm{p}=0,010)$.

Tabel 6 pertumbuhan $\mathrm{BB} / \mathrm{PB}$ dengan tempat tinggal berkorelasi $\left(\mathrm{p}=0,001 ; \mathrm{r}_{\mathrm{pbi}}=0,395\right)$. Pertumbuhan lingkar kepala dengan tempat tinggal berkorelasi $\left(p=0,005 ; r_{p}\right.$ $\left.b_{i}=0,310\right)$. Perkembangan anak berkorelasi dengan tempat tinggal $\left(\mathrm{p}=0,006 ; \mathrm{r}_{\mathrm{pbi}}=0,329\right)$. Pertumbuhan dan perkembangan anak usia 3 - 24 bulan berkorelasi dengan daerah tempat tinggal $\left(\mathrm{p}=0,05 ; \mathrm{r}_{\mathrm{pbi}}>0,3\right)$ yang menunjukkan korelasi positif dengan kekuatan lemah.

\section{Pembahasan}

Pada dasarnya, setiap anak akan melewati proses tumbuh kembang sesuai dengan tahapan usianya. Akan tetapi, banyak faktor yang memengaruhi di antaranya faktor genetik dan lingkungan sejak prenatal, perinatal, dan postnatal. Faktor lingkungan adalah faktor yang menentukan tercapai atau tidaknya potensi bawaan yang terdiri atas lingungan bio-psiko-sosial. ${ }^{1}$ Tumbuh kembang anak yang optimal berhubungan dengan lingkung- an tempat lahir dan tinggal anak. ${ }^{11}$ Anak yang lahir dan tinggal di daerah yang rawan terjadi bencana baik berupa bencana alam, perang, atau konflik bersenjata sangat berisiko tinggi mengalami kegagalan pertumbuhan dan keterlambatan perkembangan. ${ }^{6}$

Hasil penelitian mendapatkan pertumbuhan dan perkembangan anak usia 3 - 24 bulan yang tinggal di daerah konflik lebih terganggu dibandingkan dengan yang tinggal di daerah bukan konflik. Konflik yang terjadi di suatu daerah akan memengaruhi banyak sektor di antaranya sistem pemerintahan, keadaan ekonomi, keamanan, dan kesehatan yang kesemuanya akan berdampak pada kehidupan bermasyarakat. ${ }^{18,19}$ Faktor penyebab konfik dalam masyarakat yaitu perbedaan antarindividu, perbedaan kebudayaan, perbedaan kepentingan, dan perubahan sosial. ${ }^{20}$

Hasil penelitian dampak konflik peperangan secara langsung akan memperburuk kesehatan dan kelangsungan hidup dengan ditunjukkan angka kesakitan pada anak meningkat seperti malanutrisi, campak, diare, dan penyakit infeksi yang dapat menyebabkan kematian 5095\% pada anak balita di masa perang. ${ }^{21}$

Penelitian yang dilakukan oleh Jeharsae dkk. ${ }^{15} \mathrm{di}$ daerah konflik Thailand menunjukkan bahwa terjadi gangguan pertumbuhan dengan prevalensi underweight $19,3 \%$, stunting $27,6 \%$, dan wasting $7,4 \%$ serta keterlambatan perkembangan meliputi kemampuan gerak kasar, gerak halus, bahasa dan bicara, serta sosialisasi dan kemandirian yaitu $31,1 \%$.

Hasil penelitian didapatkan jenis kelamin berhubungan dengan perkembangan di daerah konflik. Penelitian 
yang dilakukan Ramli dkk. ${ }^{16}$ di Maluku yang menunjukkan bahwa usia anak, jenis kelamin, dan jumlah makan per hari merupakan faktor risiko untuk anak yang mengalami keterlambatan pertumbuhan dan perkembangan. Penelitian ini sesuai dengan penelitian yang dilakukan di Bandung, menunjukkan bahwa status ekonomi keluarga tidak berhubungan dengan perkembangan anak $(\mathrm{p}=0,336){ }^{22}$

Faktor biologis maupun lingkungan dapat memegang peran penting terhadap arti menjadi laki-laki atau perempuan. Bayi laki-laki mempunyai karakteristik tubuh yang lebih panjang dan berat serta sedikit lebih kuat. Bayi perempuan tidak seaktif laki-laki terhadap stres dan lebih besar kemungkinan berhasil melewati masa bayi. Kedua jenis kelamin sama-sama sensitif terhadap sentuhan, pola tumbuh gigi cenderung sama, bangun dari rebah dan duduk, dan berjalan pada jadwal yang sama. Bayi laki-laki dan perempuan juga mencapai titik awal perkembangan motorik semasa bayi pada saat yang sama. ${ }^{23}$

Pertumbuhan dan perkembangan anak usia 3 - 24 bulan berkorelasi dengan daerah tempat tinggal $\left(p=0,05 ; r_{p-}\right.$ $\mathrm{bi}>0,3)$ yang menunjukkan korelasi positif dengan kekuatan lemah. Hasil studi yang dilakukan di Afganistan didapatkan bahwa akibat perang terjadi kekurangan makanan, sumber air bersih, obat-obat yang kurang memadai serta traumatik yang dalam akan berpengaruh pada keadaan emosional, perilaku serta gangguan fisik, dan yang palik buruk akan menyebabkan depresi sehingga memengaruhi kesehatan terutama kesehatan ibu dan anak. ${ }^{13}$

Hasil penelitian lain menunjukkan bahwa situasi konflik bersenjata akan menyebabkan stres dalam kehidupan sehari-hari yang rentan terjadi pada perempuan dan anak sehingga akan berpengaruh pada keadaan fisik, psikologis, dan perkembangan emosional. ${ }^{20}$ Penelitian yang di lakukan Evans ${ }^{24}$ menunjukkan bahwa konflik peperangan di suatu daerah secara langsung akan memperburuk kesehatan dan kelangsungan hidup dengan ditunjukkan angka kesakitan pada anak meningkat seperti malnutrisi, campak, diare, dan penyakit infeksi yang dapat menyebabkan kematian $50-95 \%$ pada anak balita di masa perang.

Konflik menyebabkan kurangnya stimulasi yang diberikan baik oleh orangtua maupun keluarga. Selain itu, kurangnya pendidikan kesehatan dan deteksi dini oleh tenaga kesehatan menyebabkan gangguan pertumbuhan dan perkembangan kurang dapat terdeteksi.

\section{Kesimpulan}

Pertumbuhan dan perkembangan anak usia 3 - 24 bulan yang tinggal di daerah konflik lebih terganggu dibandingkan dengan yang tinggal di daerah bukan konflik. Terdapat korelasi tempat tinggal daerah konflik dengan pertumbuhan dan perkembangan anak usia 3 - 24 bulan, dan jenis kelamin anak memengaruhi perkembangan anak usia 3 - 24 bulan di daerah konflik.

\section{Saran}

Upaya pemerintah daerah sangat diperlukan dalam membuat rasa aman dan nyaman pada masyarakat daerah konflik, mencanangkan program yang dapat memperbaiki pertumbuhan dan perkembangan anak serta diperlukan kesadaran orangtua dalam memperhatikan pemberian asupan gizi dan melakukan stimulasi yang berulang dan konsisten sehingga proses pertumbuhan dan perkembangan anak akan baik.

\section{Ucapan Terima Kasih}

Terima kasih pada Farid, Ir., dr., SpOG, M.Kes, M.Pd, Prof. Dr Firman F Wirakusumah dr., SpOG(K), Prof. H. Herry Gana, dr., SpA(K), Ph.D, Prof. Dr Kusnandi Rusmil, dr., $\operatorname{SpA}(\mathrm{K}), \mathrm{MM}$, yang telah memberikan masukan dalam penyusunan penelitian ini.

\section{Daftar Pustaka}

1. Soedjatmiko. Deteksi dini gangguan tumbuh kembang balita. Sari Pediatri. 2001; 3: 175-88.

2. Kementrian Kesehatan Republik Indonesia. Pedoman pelaksanaan stimulasi deteksi dan intervensi dini tumbuh kembang anak di tingkat pelayanan kesehatan dasar. Jakarta: Departemen Kesehatan Republik Indonesia; 2010.

3. Wong DL, Hockenberry-Eatom M, Wilson D, Winkelstein ML, Schwartz P. Buku ajar keperawatan pediatrik. Jakarta: EGC; 2008

4. Soetjiningsih. Upaya peningkatan kualitas tumbuh kembang anak. Dalam: Ranuh G, Penyunting. Tumbuh kembang anak. Jakarta: EGC; 1995. hal. 1-140

5. Asiyah S, Harjito K, Suwoyo. Efektivitas metode stimulasi satu jam bersama ibu terhadap perkembangan anak usia 12-24 bulan. Jurnal Penelitian Kesehatan Suara Forikes. 2010 April; I: 105-14.

6. Ariani, Yosoprawoto M. Usia anak dan pendidikan ibu sebagai faktor risiko gangguan perkembangan anak. Jurnal Kedokteran Brawijaya. 2012; 27: 118-21.

7. Rosales FJ, Reznick JS, Zeisel SH. Rosales FJ, Reznick JS, Zeisel SH. Understanding the role of nutrition in the brain and behavioral development of toddlers and preschool children: identifying and addressing methodological barriers. Nutritional Neurosci. 2009 Oct; 12 (5): 190202.

8. Tang KM, Chen TY, Lau VW, Wu MM. Clinical profile of young children with mental retardation and developmental delay in Hong Kong. Hong Kong Med J. Xianggang yi xue za zhi/Hong Kong Academy of Medicine. 2008 Apr; 14 (2): 97-102.

9. Pediatrics AAo. Developmental surveillance and screening of infants and youing children. Pediatrics. 2001 July; 108 (1): 192.

10. Litbangkes B. Riset kesehatan dasar. Jakarta: Kementerian Kesehatan Republik Indonesia; 2010.

11. Hidayat AAA. Optimalisasi penggunaan KPSP pada keluarga sebagai upaya pencegahan gangguan perkembangan anak. Prosiding dalam Seminar Sains; 2010 . 
12. Aprianingsih. Indikator perbaikan kesehatan lingkungan anak. Jakarta: EGC; 2009.

13. Assefa F, Zahir M, Salama PS. Melnutrition and mortality in Kohistan District, Afganistan. JAMA. 2001 Apr; 21: 2723.

14. Prasad. Children in conflict zones. MUFI. 2009; 65: 2-35.

15. Pelletier DL. The relationship between child antropometry and mortality in developing countries: implications for policy, program, and future research. Journal of Nutrition. 1994; 124: 2047S-81.

16. Jeharse R, Sangthong R, Wichaidit W, Chongsuvivatwong V. Growth and development of children aged 1-5 years in low-intensity armed conflict areas in Southern Thailand: a community-based survey. Conflict and Health. 2013; 7 (1): 8.

17. Ramli, Agho KE, Inder KJ, Bowe SJ, Jacobs J, Dibley MJ. Prevalence and risk factors for stunting and severe stunting among under-fives in North Maluku province of Indonesia. BMC Pediatrics. 2009; 9: 64.

18. Menteri Kesehatan Republik Indonesia. Peraturan Menteri Kesehatan RI Nomor 1464 tentang Izin dan Penyelenggaraan Praktik Bidan. Jakarta:
Kementrian Kesehatan Republik Indonesia; 2010.

19. Suradi A. Policing dan kamtibmas dalam rangka pemeliharaan kedamaian pasca konflik di Indonesia [Internet]. 2009 [diakses tanggal 15 Januari 2013]. Diunduh dalam: www.academia.edu/5481898/kamtibmas.

20. Nasution A. Penanganan konflik sosial. Majalah Humanis. 2012; 1 (7)

21. Jacobs D. Protecting children from the scouirge of war. The Consultative Group Early Childhood Care and Development. Washington DC: World Bank; 1999.

22. Mashlm T, Takano T, Nakamura K, Kizuki M, Hemat S, Watanabe M, et al. Factors associated with the health and nutritional status of children under 5 years of age in Afganistan: family behaviouir related to women and past experience of war-related hardships. BMC Public Health. 2008: 8: 301.

23. Gunawan G, Fadlyana E. Hubungan statuys gizi dan perkembangan usia 12 tahun. Sari Pediatri. 2011; 13 (2): 142-6.

24. Evans JL. Children as zones of peace: working with young children affected by armed violence. New York: The Consultative Grouip Early Childhood Care and Development; 1996. 